\title{
Doxycycline Protects Thymic Epithelial Cells from Mitomycin C-Mediated Apoptosis In Vitro via Trx2-NF-kB-Bcl-2/ Bax Axis
}

\author{
Jun Wang ${ }^{a, b}$ Ya Zhuo ${ }^{a, c}$ Lei Yina,d Hui Wang ${ }^{a}$ Yanqiu Jiang ${ }^{a}$ Xia Liu ${ }^{a}$ \\ Miaomiao Zhang ${ }^{a}$ Fengyi Du $^{a}$ Sheng Xia ${ }^{a}$ Qixiang Shao
}

\begin{abstract}
aDepartment of Immunology, and Jiangsu Key Laboratory of Medical Science and Laboratory Medicine, School of Medicine, Jiangsu University, Zhenjiang, 'Department of Medical Laboratory, Wuhan Medical and Health Center for Women and Children, Wuhan, 'Department of Laboratory Medicine, People's Hospital of Hebi, Hebi, dDepartment of Laboratory Medicine, Handan Central Hospital of Hebei, Handan, China
\end{abstract}

\section{Key Words}

Doxycycline $•$ Mitomycin C $・$ Trx2 $・ N F-K B \cdot$ Thymic epithelial cell $•$ Anti-apoptosis

\begin{abstract}
Background/Aims: Age-associated and stress-induced involution of the thymus is accompanied by reduced numbers of thymic epithelial cells (TECs) and severe reduction in peripheral $T$ cell repertoire specificities. These events seriously affect immune function, but the mechanisms involved are unclear. Our preliminary findings showed that doxycycline (Dox) could drive the proliferation of a TEC line (MTEC1 cells) partially via the MAPK signaling pathway. Dox can also up-regulate IL- 6 and GM-CSF expression via the NF-KB and MAPK/ERK pathways. Herein, we investigate the effects and mechanisms used by Dox that protect against mitomycin C (MMC)-induced MTEC1 cell apoptosis. Methods: MTEC1 cells were treated with Dox, MMC, and Dox plus MMC for different amounts of time. The expression of Trx2, NF$\mathrm{KB}, \mathrm{BCl}-2$, and $\mathrm{Bax}$ proteins were then detected by western blotting. Results: Our findings show that Dox protects MTEC1 cells from MMC-induced apoptosis. Dox up-regulated the expression of Trx2 and promoted NF-kB phosphorylation. Meanwhile, Dox also increased the expression of $\mathrm{BCl}-2$, partially reduced the expression of $\mathrm{Bax}$, and normalized the ratio of $\mathrm{BCl}-$ 2 to Bax. Conclusion: Dox exerts an anti-apoptosis function via the NF-KB-Bcl-2/Bax and Trx2-ASK1/JNK pathways in vitro. Therefore, Dox may represent a drug that could be used to attenuate thymic senescence, rescue thymic function, and promote $T$ cell reconstitution.
\end{abstract}




\section{Cellular Physiology Cell Physiol Biochem 2016;38:449-460 \begin{tabular}{ll|l} 
DOI: 10.1159/000438642 & O 2016 The Author(s). Published by S. Karger AG, Basel \\
www.karger.com/cpb
\end{tabular} \\ Wang et al.: Dox Protects MTEC1 Cell from Apoptosis}

\section{Introduction}

The thymus is the central organ for $\mathrm{T}$ cell development. Within the thymus, thymic epithelial cells (TECs) play a critical role in this process. However, the thymus undergoes degeneration and atrophy at early time points in humans and mice, and accelerates with ageing. Thymic atrophy can be caused by infectious disease (such as HIV infection), hunger, radiotherapy, chemotherapy, transplant rejection, immune suppression, and other serious diseases. The most common trigger for thymic atrophy is age-related degeneration and atrophy. Thymus degeneration and atrophy not only decrease thymic output, but also reduce thymic size and TEC cellularity. Moreover, the thymic tissue structure changes markedly $[1,2]$. Currently, we can repopulate myeloid and erythroid cells by infusing various hematopoietic growth factors in the clinic, but reconstituting lymphatic cells remains very difficult, especially for $\mathrm{T}$ cells $[1,3,4]$. If we can better understand the mechanism underlying thymic atrophy, in particular the apoptosis of TECs, it will accelerate efforts to reconstruct T cells in patients immunodeficiency caused by reasons that include senile immunodeficiency, infection (HIV), and transplant rejection [5]. However, the mechanism underlying the apoptosis of TECs remains unclear.

Doxycycline (Dox), a tetracycline antibiotic, has been found to trigger both physiological and pathological processes to regulate cellular apoptosis $[6,7]$, immune responses $[8,9]$, and inflammation [10], in addition to its well-known antimicrobial effects. Our preliminary data show that Dox can drive proliferation in part via the Ras-MAPK signaling pathway [11] and also up-regulate expression of IL- 6 and GM-CSF through the MAPK/ERK and NF$\kappa \mathrm{B}$ pathways [12]. Cellular apoptosis is the most prominent feature of thymic involution. Mitomycin C (MMC), an anti-tumor antibiotic agent, acts via the inhibition of DNA and RNA synthesis, eventually inducing cell apoptosis. Hence, it may mimic TEC atrophy when used to treat cells in vitro.

In the present study, we observed the the protective effect of MTEC cells treated with Mitomycin-C. The results show that Dox enhances the expression of Trx2 and promoted NF- $\kappa \mathrm{B}$ phosphorylation. Meanwhile, Dox also increased the expression of Bcl-2, partially reduced the expression of Bax, and normalized the ratio of Bcl-2 to Bax. Dox exerts an antiapoptosis function via the NF- $\mathrm{BB}-\mathrm{Bcl}-2 / \mathrm{Bax}$ and Trx2-ASK1/JNK pathways in vitro. Taken together, our results implicate the therapeutic potential of Dox on T cell reconstitution.

\section{Materials and Methods}

\section{Chemicals and reagents}

Dulbecco's Modified Eagle's Medium (DMEM) and fetal bovine serum (FBS) were purchased from Life Technologies Corporation (California, USA). Primary antibodies: rabbit anti-Trx2 (ab71261) pAb were purchased from Abcam (Hong Kong) Ltd. (New Territories, HK, China), rabbit anti-NF- $\kappa B-p 65$ (M270) pAb, rabbit anti-p-NF-кB-p65 (S276) pAb, rabbit anti Bcl-2 (BS1511) pAb and rabbit anti- $\beta$-actin pAb were purchased from Bioworld Technology, Inc. (Nanjing, China); Rabbit anti-Bax was obtained from Proteintech Group, Inc. (Chicago, USA). Secondary antibody: HRP-conjugated goat anti-rabbit IgG (H+L) pAb was bought from Jackson ImmunoResearch laboratories, Inc. (Pennsylvania, USA). Protease inhibitors cocktail was a product of Beyotime Institute of Biotechnology (Shanghai, China). AnnexinV-FITC/PI was purchased from MultiSciences Biotech Co. Ltd (Hangzhou, China). Mitomycin C (MMC, Kyowa Hakko Kogyo Ltd., Tokyo, Japan). Cell Counting kit-8 (CCK-8, Dojindo Laboratories, Kumamoto, Japan). Doxycycline (Dox), DMSO and Hoechst 33342 were purchased from Sigma-Aldrich Shanghai Trading Co. Ltd. (Shanghai, China). BAY11-

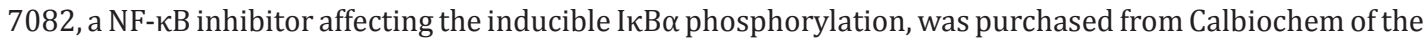
Merck Group (Shanghai, China). The inhibitor was dissolved in DMSO (10 mM) and the final concentration of DMSO in culture medium was $0.1 \%$. An enhanced chemiluminescence (ECL) Western blotting detection system was obtained from Millipore (Billerica, MA). 


\section{Cellular Physiology Cell Physiol Biochem 2016;38:449-460

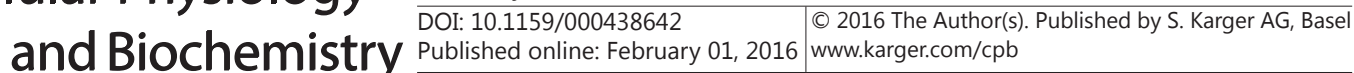 \\ Wang et al.: Dox Protects MTEC1 Cell from Apoptosis}

Cell culture

Mouse thymic epithelial cell line 1 (MTEC1) is a kind gift of Prof. Chen's laboratory [13], which support the functional maturation of CD4 signal-positive thmocytes in vitro [14]. The cells were cultured in DMEM supplemented with $10 \%$ heat-inactivated FBS in a humidified incubator at $37^{\circ} \mathrm{C}$ with $5 \% \mathrm{CO} 2$.

\section{Cell viability assay}

Cell viability was measured by CCK-8, according to the manufacturer's instructions and performed as previously described [15]. Briefly, MTEC1 cells were seeded into 96-well plates (Corning Inc., USA) at a density of $1 \times 10^{4} /$ well in total volumes of $100 \mu \mathrm{L}$ and cultured overnight at $37^{\circ} \mathrm{C}$. All the media from the plates were removed and washed by PBS (pH7.4). Dox in serial dilutions $(0,0.1,1,10$ and 100 $\mu \mathrm{g} / \mathrm{mL}$ ) were added to a total volume of $100 \mu \mathrm{L}$ culture media, cells were cultured for 12,24 and $36 \mathrm{~h}$ with triplicate wells for each concentration. MMC in serial dilutions $(0,0.2,2,20$ and $200 \mu \mathrm{g} / \mathrm{mL})$ was added to a total volume of $100 \mu \mathrm{L}$ culture media, cells were cultured for 12,24 and $36 \mathrm{~h}$ with triplicate wells for each concentration. Also, Dox $(10 \mu \mathrm{g} / \mathrm{mL})$ pretreated MTEC1 cells for $12 \mathrm{~h}$ and MMC $(20 \mu \mathrm{g} / \mathrm{mL})$ treated for 12 , 24 and $36 \mathrm{~h}$. CCK-8 $(10 \mu \mathrm{L} /$ well $)$ was added $4 \mathrm{~h}$ prior to the end of culture, after which the absorbance at $450 \mathrm{~nm}$ was measured using a microplate reader (Bio-Tek Instruments Inc., Vermont, USA). All experiments were replicated in triplicate wells and repeated three independent times.

\section{Hoechst 33342 staining for apoptosis assessment}

MTEC1 cells were seeded at a density of $1 \times 10^{5} /$ well in 24-well plates in total $1 \mathrm{~mL}$ volume and pretreated with or without Dox (10 $\mu \mathrm{g} / \mathrm{mL})$ for $12 \mathrm{~h}$, and co-cultured with $20 \mu \mathrm{g} / \mathrm{mL}$ MMC for another 24 or $36 \mathrm{~h}$. Hoechst 33342 solution was added into media at a final concentration of $5 \mu \mathrm{g} / \mathrm{mL}$. The cells were continuous cultured in $5 \% \mathrm{CO}_{2}$ at $37^{\circ} \mathrm{C}$ for $30 \mathrm{~min}$. After that, cells were washed twice with PBS and fixed by $4 \%$ paraformaldehyde. The cellular morphology were observed and imaged under Zeiss Axio Observer A1 inverted stand Fluorescence Microscope (Carl Zeiss Group, Baden-Württemberg, Germany). Apoptosis was defined as the presence of nuclear fragmentation on Hoechst 33342 staining.

\section{Annexin V-FITC apoptosis assay}

Cells apoptosis were detected by staining with an AnnexinV-FITC/PI apoptosis detection kit according to the manufacturer's protocol. Briefly, MTEC1 cells were seeded at a density of $1 \times 10^{5} /$ well in 24 -well plates in total $1 \mathrm{~mL}$ volume. Cells were cultured overnight and washed with PBS (pH7.4), the media was $100 \%$ change into fresh pre-warmed complete media. After that, MTEC1 cells were pretreated with or without Dox $(10 \mu \mathrm{g} / \mathrm{mL})$ for $12 \mathrm{~h}$, and co-cultured with or without $20 \mu \mathrm{g} / \mathrm{mL}$ MMC for another $24 \mathrm{~h}$ or $36 \mathrm{~h}$. MTEC1 cells were washed with PBS ( $\mathrm{pH}=7.4)$, digested with $2.5 \%$ trypsin-EDTA, collected in DMEM medium with $10 \% \mathrm{FBS}$, and the cell suspension was centrifuged at $800 \mathrm{rpm} / \mathrm{min}$ for $10 \mathrm{~min}$. Subsequently, the cells were resuspended in $250 \mu \mathrm{L}$ Annexin V binding buffer, and incubated with $5 \mu \mathrm{L}$ PI and $2.5 \mu \mathrm{L}$ Annexin V-FITC in dark for $15 \mathrm{~min}$ at room temperature. Apoptotic cells were identified and quantified using an Accuri ${ }^{\mathrm{TM}} \mathrm{C} 6$ Flow Cytometry (Becton, Dickinson and Company, California, USA).

\section{Quantitative real-time $P C R$}

MTEC1 cells $\left(5 \times 10^{5}\right)$ were cultured in 6-well culture plates overnight and treated with or without different concentration of Dox, MMC and Dox plus MMC for different time. Quantitative real-time PCR (QPCR) analysis was performed as previously described [16]. Total RNA was isolated using TrizolTM reagent (Life Technologies), and cDNA was synthesized by a reverse transcriptase, RevertAid First Stand cDNA Synthesis Kit (M-MuLV Reverse Transcriptase) (Fermentas, Thermo Fisher Scientific (China) Co., Ltd, Beijing, China). The QPCR were performed on an Bio-Rad real-time instrument CFX 96 using SYBR Premix EX TaqTMII (TaKaRa, Dalian, China). Relative mRNA expression level was normalized to Housekeeping gene $\beta$-actin mRNA expression. Values are presented as the means \pm SEM of triplicate measurements. The primers using for QPCR amplification of Trx2, Bcl-2, Bax and $\beta$-actin are listed in Table 1.

\section{Western blot}

MTEC1 cells were seeded into 6-well culture plates at a density of $5 \times 10^{5} /$ well, cultured overnight and treated with Dox, MMC and Dox plus MMC for different time. The MTEC1 cells were lysed in RIPA buffer (50 mM Tris-HCL with pH 7.4, 1\% TritonX-100, 1\% sodium deoxycholic acid, $0.1 \%$ SDS, 2 mM EDTA 


\begin{tabular}{|c|c|}
\hline Cellular Physiology & $\begin{array}{l}\text { Cell Physiol Biochem 2016;38:449-460 } \\
\begin{array}{l|l}\text { DOI: } 10.1159 / 000438642 & \text { 2016 The Author(s). Published by S. Karger AG, Basel }\end{array}\end{array}$ \\
\hline and Biochemistry & 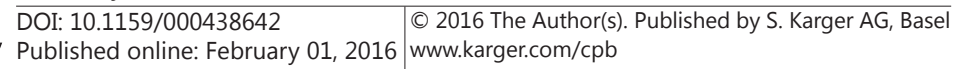 \\
\hline
\end{tabular}

Table 1. Primer sequences used for real-time PCR analysis

\begin{tabular}{lllcc}
\hline Gene & & Primer sequence $\left(5^{\prime} \rightarrow 3^{\prime}\right)$ & Sizes & $\begin{array}{c}\text { Anneal } \\
\text { Temperature }\end{array}$ \\
\hline$\beta$-actin & Sense & TGGAATCCTGTGGCATCCATGAAAC & $349 \mathrm{bp}$ & $58^{\circ} \mathrm{C}$ \\
& Anti-sense & TAAAACGCAGCTCAGTAACAGTCCG & & \\
$\operatorname{Tr} 22$ & Sense & AGGAAACCAGAAGCCGAACA & $179 \mathrm{bp}$ & $58^{\circ} \mathrm{C}$ \\
& Anti-sense & ACCAAGGCCCAGCTAACTCA & & \\
Bcl-2 & Sense & GCCGAGAAGAAGGGAGAATC & $302 \mathrm{bp}$ & $58^{\circ} \mathrm{C}$ \\
& Anti-sense & CAAACAAATACATAAGGCAACCAC & & \\
Bax & Sense & CAGGATGCGTCCACCAAGAA & $591 \mathrm{bp}$ & $58^{\circ} \mathrm{C}$ \\
& Anti-sense & GCAAAGTAGAAGAGGGCAACCAC & & \\
\hline
\end{tabular}

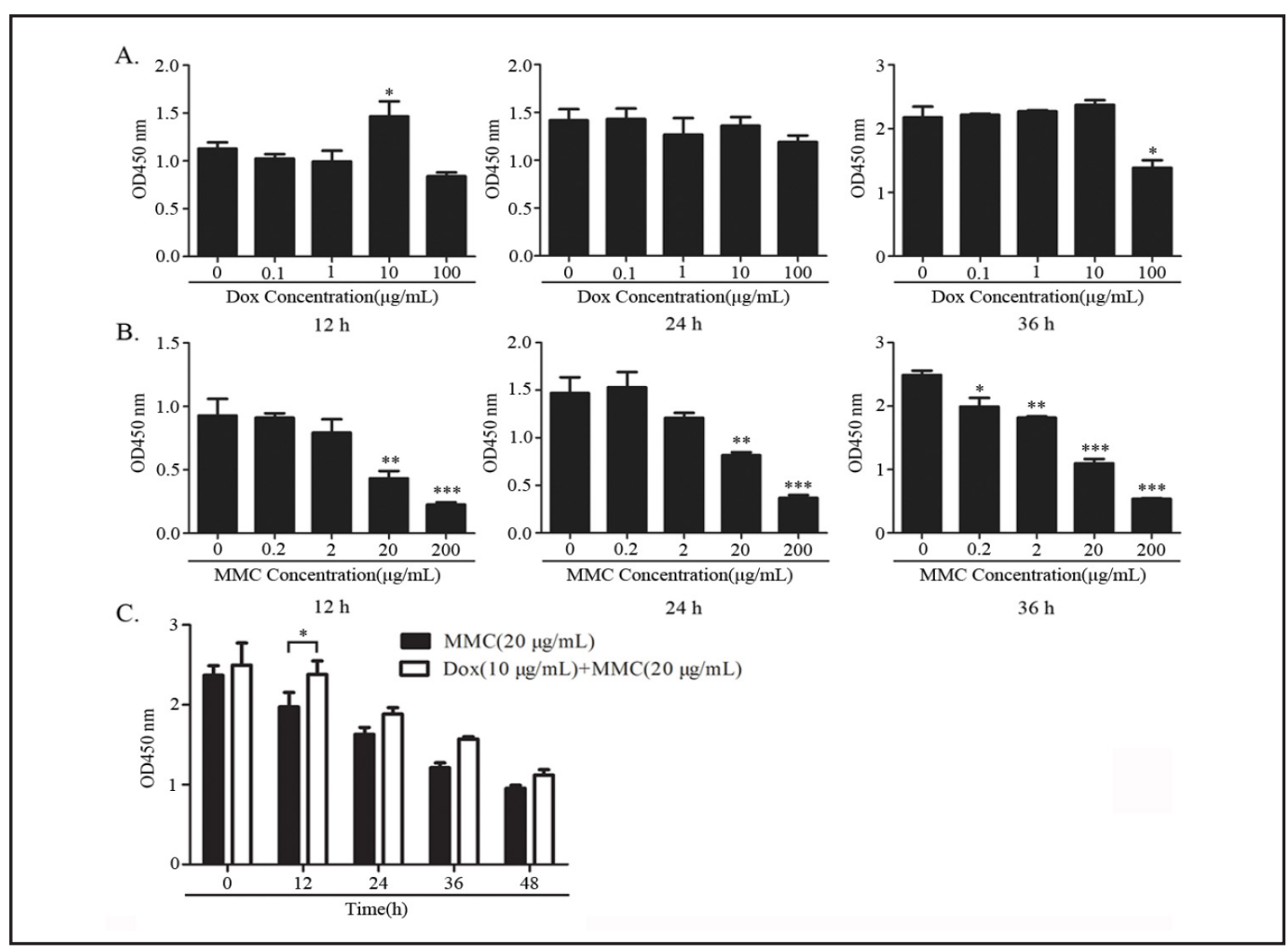

Fig. 1. Analysis the viability of MTEC1 cells after treatment with Dox, MMC and Dox plus MMC (A) MTEC1 cells were treated with different concentration of Dox for 12, 24 and $36 \mathrm{~h}$, cells viability was evaluated by CCK-8 assay. (B) MTEC1 cells were treated with different concentration of MMC for 12, 24 and $36 \mathrm{~h}$, cells viability was evaluated by CCK-8 assay. (C) Pretreated with or without Dox for $12 \mathrm{~h}$, MTEC1 cells were cultured with MMC for another 12, 24, 36 and 48 h, cell viability was evaluated by CCK-8 assay. Data are represented as the mean $\pm \mathrm{SD}$ of three independent experiments. ${ }^{*} p<0.05$, compared with the control.

and protease inhibitors cocktail), plated on ice for $20 \mathrm{~min}$, sonicated and then centrifuged at 14,000 $\mathrm{g}$ for $10 \mathrm{~min}$ at $4^{\circ} \mathrm{C}$. After protein concentration, quantification was performed with the modified Bradford assay (Beyotime Institute of Biotechnology, Shanghai, China), $60 \mu \mathrm{g}$ total proteins were subsequently used for western blotting with primary antibodies against Trx2, NF- $\kappa \mathrm{B}, \mathrm{p}-\mathrm{NF}-\kappa \mathrm{B}, \mathrm{Bcl}-2$, Bax and $\beta$-actin. Blots bands were visualized with an enhanced chemiluminescence kit (ECL) (GE Healthcare) and scanned by the ImageQuant LAS 400 mini ECL system (GE Healthcare, USA).

\section{Statistical analysis}

All data are shown as mean \pm standard deviation (SD). One-way analysis of variation (ANOVA) and 2 -sided Student's t test were used. A value of $\mathrm{p}<0.05$ was accepted as statistically significant.

\section{KARGER}




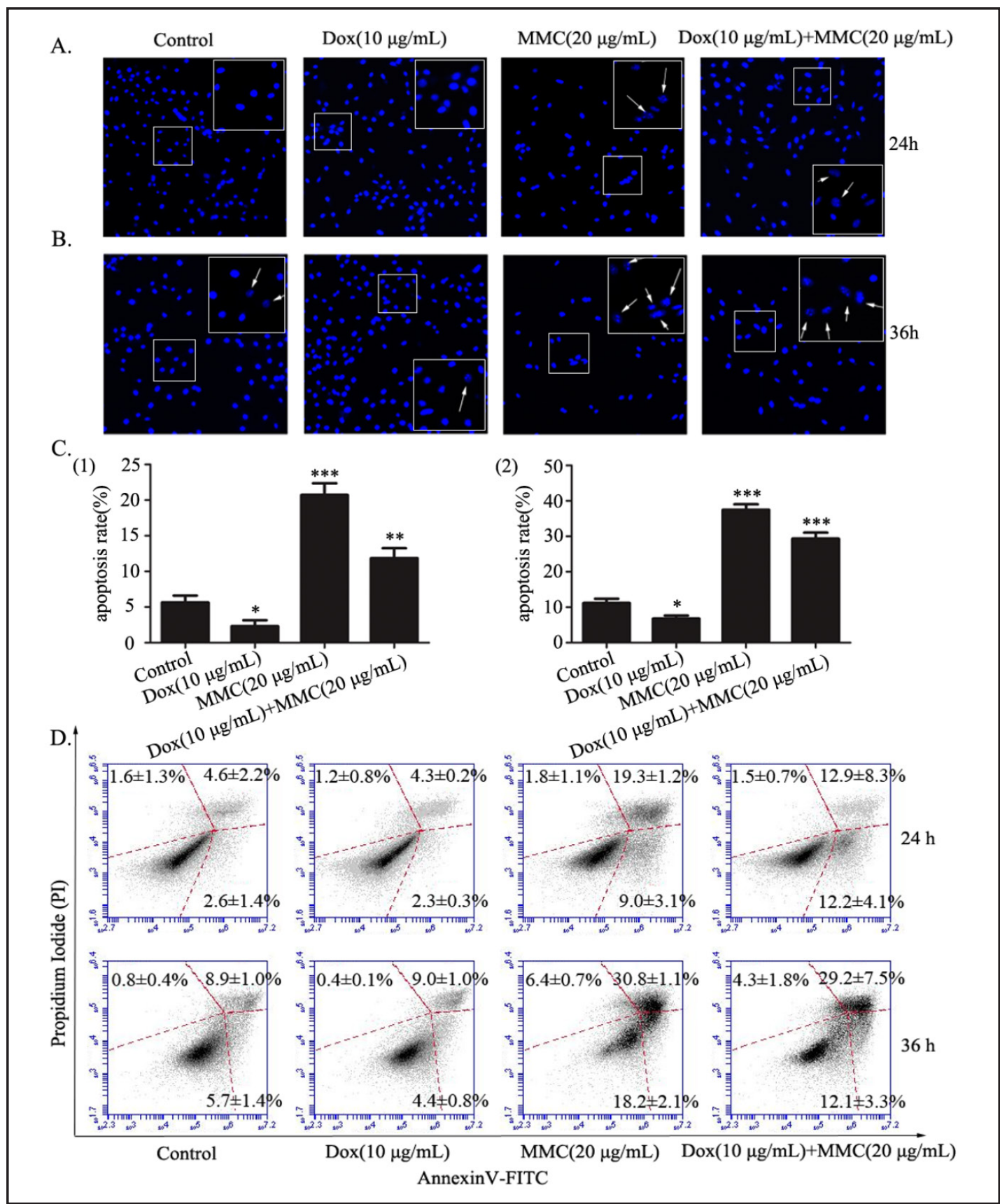

Fig. 2. MMC induced apoptosis of MTEC1 cells is reversed by DOX (A) and (B) Pretreated with or without Dox for $12 \mathrm{~h}$, MTEC1 cells were treated with MMC for another $24 \mathrm{~h}$ and $36 \mathrm{~h}$, Hoechst 33342 staining (original magnification, $\times 100, \times 200$ ) was used to determine the apoptosis. (C) Arrows indicate cells with nuclear fragmentation. The apoptotic cells were counted from five high magnifications $(\times 200)$. (D) MTEC1 cells were treated as it did before and cells apoptosis were detected by staining with an AnnexinV-FITC/PI apoptosis detection kit. MTEC1 cells group was set as control group. Data are represented as the mean \pm SD of three independent experiments. ${ }^{*} \mathrm{p}<0.05$, compared with control group.

\section{Results}

Doxycycline reversed mitomycin C-induced cell death in MTEC1 cells

The effect of Dox, MMC and Dox plus MMC on MTEC1 cells viability was measured by CCK-8 assay after incubation in medium at different concentrations and different times. We 


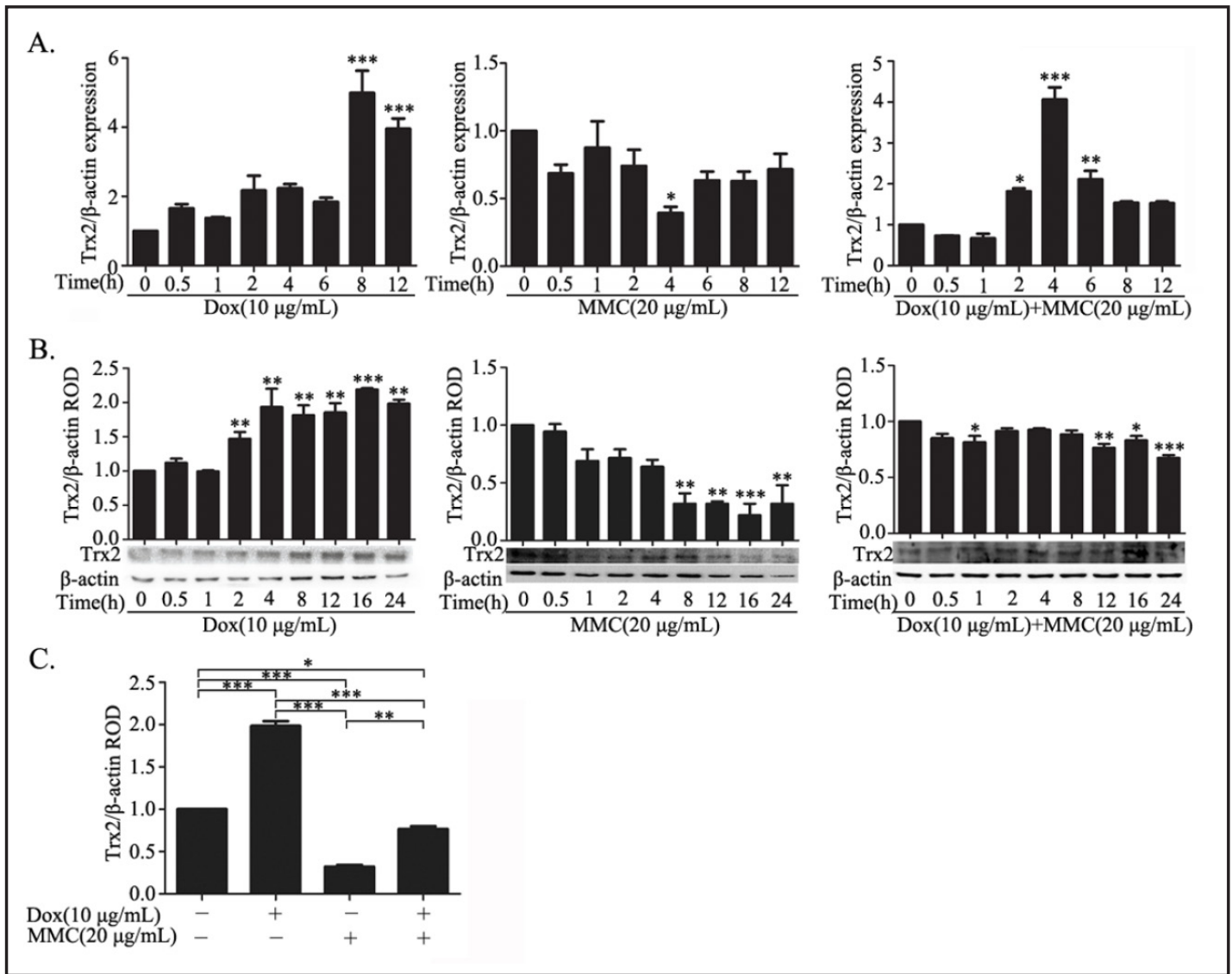

Fig. 3. Dox promotes the activation of Trx2 in MTEC1 cells. (A) Trx2 expression at mRNA level in MTEC1 cells were analyzed by real-time PCR after MTEC1 cells were treated with Dox, MMC and Dox plus MMC for different time. The ratio of the target gene versus $\beta$-actin at $0 \mathrm{~h}$ was set as 1 . (B) Trx2 expression at protein level in MTEC1 cells were analyzed by western blot after MTEC1 cells was treated with Dox, MMC and Dox plus MMC for different time. (C) Trx2 expression in MTEC1 cells pretreated with Dox for $12 \mathrm{~h}$ and then treated with MMC for another 12 h. ${ }^{*} p<0.05,{ }^{* *} p<0.01,{ }^{* * *} p<0.005$, compared with "0 h". ROD: relative optical density.

found that MMC obviously induced cell death in MTEC1 cells and Dox rescued cells from cell death in dose- and time- dependent manner, the most appropriate concentrations of Dox was $10 \mu \mathrm{g} / \mathrm{mL}$ (Fig. 1).

Dox can convert MTEC1 cells apoptosis induced by MMC

To declare the effect of Dox on the MTEC1 cells, the Hoechst 33342 staining and Annexin V-FITC assay were used to evaluate the apoptosis in MTEC1 cells treated with MMC, Dox and MMC plus Dox. Compared to control, less nuclear fragmentations were detected in MTEC1 cells treated with Dox plus MMC than that of treated with MMC, but more than that of treated with Dox (Fig. 2A and B). The apoptosis rates were evaluated according with the presence of nuclear fragmentations (Fig. 2C). To further confirm the protection effect of Dox, we use FCM to detect the apoptosis with Annexin V-FITC/PI double staining. Likewise, Dox could rescue cells treated with MMC from apoptosis (Fig. 2D).

Dox promote the activation of Trx2 in MTEC1 cells

In our previous study we found that Dox can up-regulate the Trx2 expression analyzed with surface-enhanced laser desorption/ionization-time of flight (SELDI-TOF) MS (data not show). However, Trx2 play an important role in regulation of the mitochondrial 


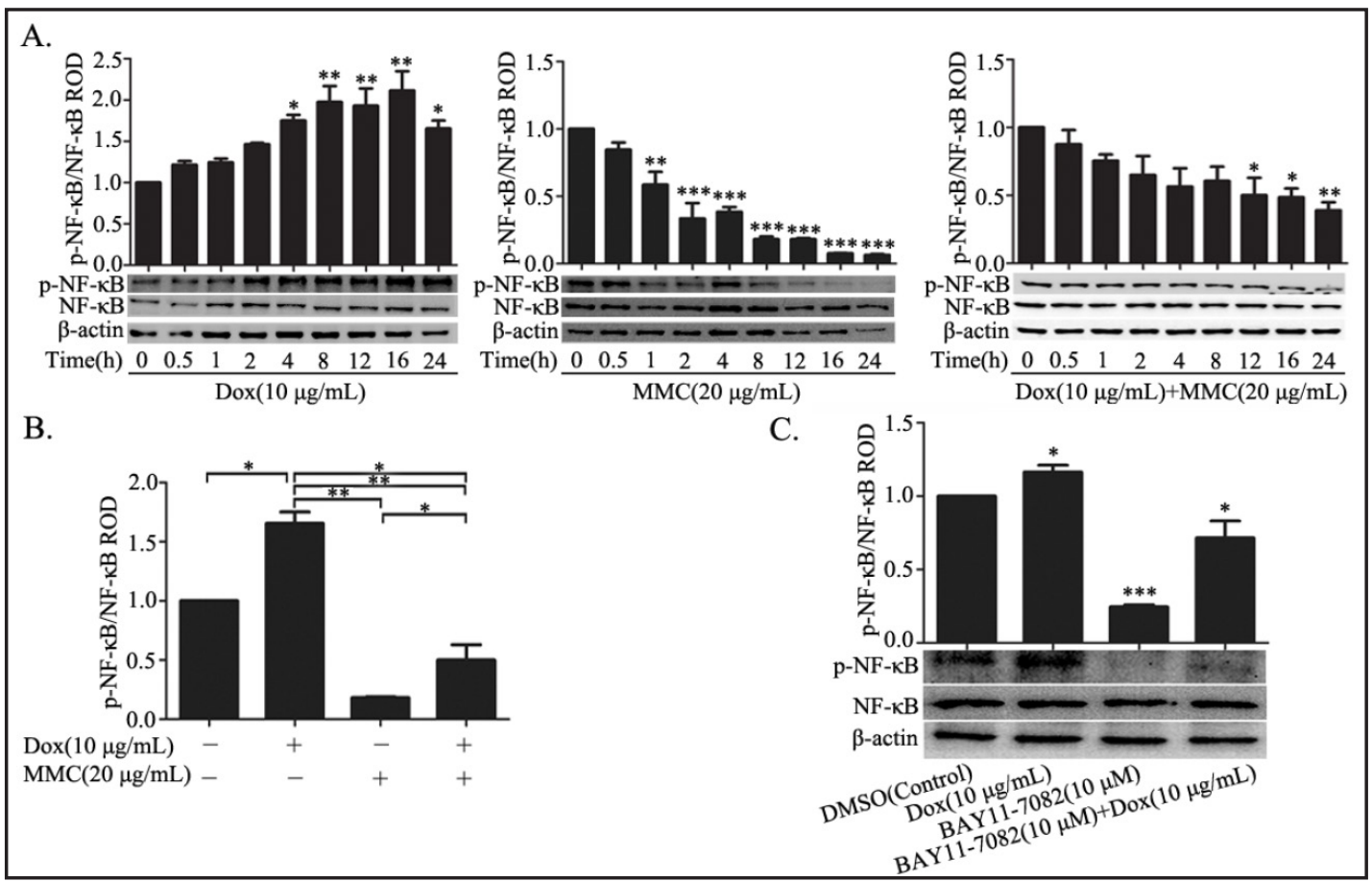

Fig. 4. The effect of Dox on NF- $\kappa B$ levels in MTEC1 cells. (A) p-NF- $\kappa B$ protein expression in MTEC1 cells were analyzed by western blot after MTEC1 cells was treated with Dox, MMC and Dox plus MMC for different time. (B) The p-NF- $\mathrm{B} / \mathrm{NF}-\kappa \mathrm{B}$ ROD in MTEC1 cells pretreated with Dox for $12 \mathrm{~h}$ and then treated with MMC for another $12 \mathrm{~h}$. (C) MTEC1 cells were treated with Dox (4 h), phosphorylation of I $\mathrm{B} \alpha$ inhibitor BAY11$7082(1 \mathrm{~h})$ and BAY11-7082 plus Dox, p-NF- $\mathrm{BB}$ protein expression were analyzed by western blot. Data are presented as fold increases or decreases as compared with 0 h. ${ }^{*} p<0.05,{ }^{* *} p<0.01,{ }^{* * *} p<0.005$, ROD: relative optical density.

membrane potential and in protection against oxidant-induced apoptosis. Therefore, we speculate that Dox may reverse cells from apoptosis via upregulating Trx 2 expression. The results showed that Dox rescued the expression of Trx 2 treated with MMC both in mRNA and protein levels (Fig. 3A, B and C).

The effect of Dox on NF- $\kappa$ B levels in MTEC1 cells

To explore the further mechanism, we investigated the Trx2 signal pathway in Dox treated MTEC1 cells. NF- $\kappa B$ is known to be downstream of Trx2, and the p65 subunit of NF$\kappa B$ can interact with Trx2 in the oxidized state [17]. So we detected the phosphorylation level of NF- $\kappa$ B. As shown in Fig. 4A, Dox increased phosphorylation of NF- $\kappa$ B as early as $4 \mathrm{~h}$ after treatment, while it began to decrease after treated with MMC $1 \mathrm{~h}$. However, Dox could partly reverse the decreasing of phosphorylation of NF- $\mathrm{\kappa B}$ when pretreated with Dox. To confirm this phenomenon, we used $10 \mu \mathrm{M}$ BAY11-7082 (an inhibitor of the phosphorylation of I $\mathrm{B} \alpha$ ) to pretreated the MTEC1 cells for $1 \mathrm{~h}$, and then added Dox $(10 \mu \mathrm{g} / \mathrm{mL})$ for $4 \mathrm{~h}$, it was found that Dox could reverse the inhibition effect of BAY11-7082 on NF- $\mathrm{KB}$ (Fig. 4C).

The effect of Dox on Bcl-2/Bax levels in MTEC1 cells

Bcl-2 families play a critical role in cell survival and apoptosis, they consist of two sub-groups: the anti-apoptotic proteins and the pro-apoptotic proteins. Bcl-2 is a very important protein which can inhibit the cell apoptosis, but Bax promote cell apoptosis [18, 19]. The ratio of Bcl-2/Bax determines whether a cell will survive or undergo apoptosis [20]. Since Bcl-2 and Bax are downstream of NF- $\kappa \mathrm{B}$ [21], we speculated that Dox rescues cells from apoptosis via NF- $\kappa \mathrm{B}$ to regulate the balance between $\mathrm{Bcl}-2$ and Bax. We analyze the expression Bcl-2 and Bax by real-time PCR and Western blot in Dox treatment MTEC1 cells.

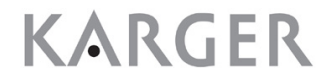




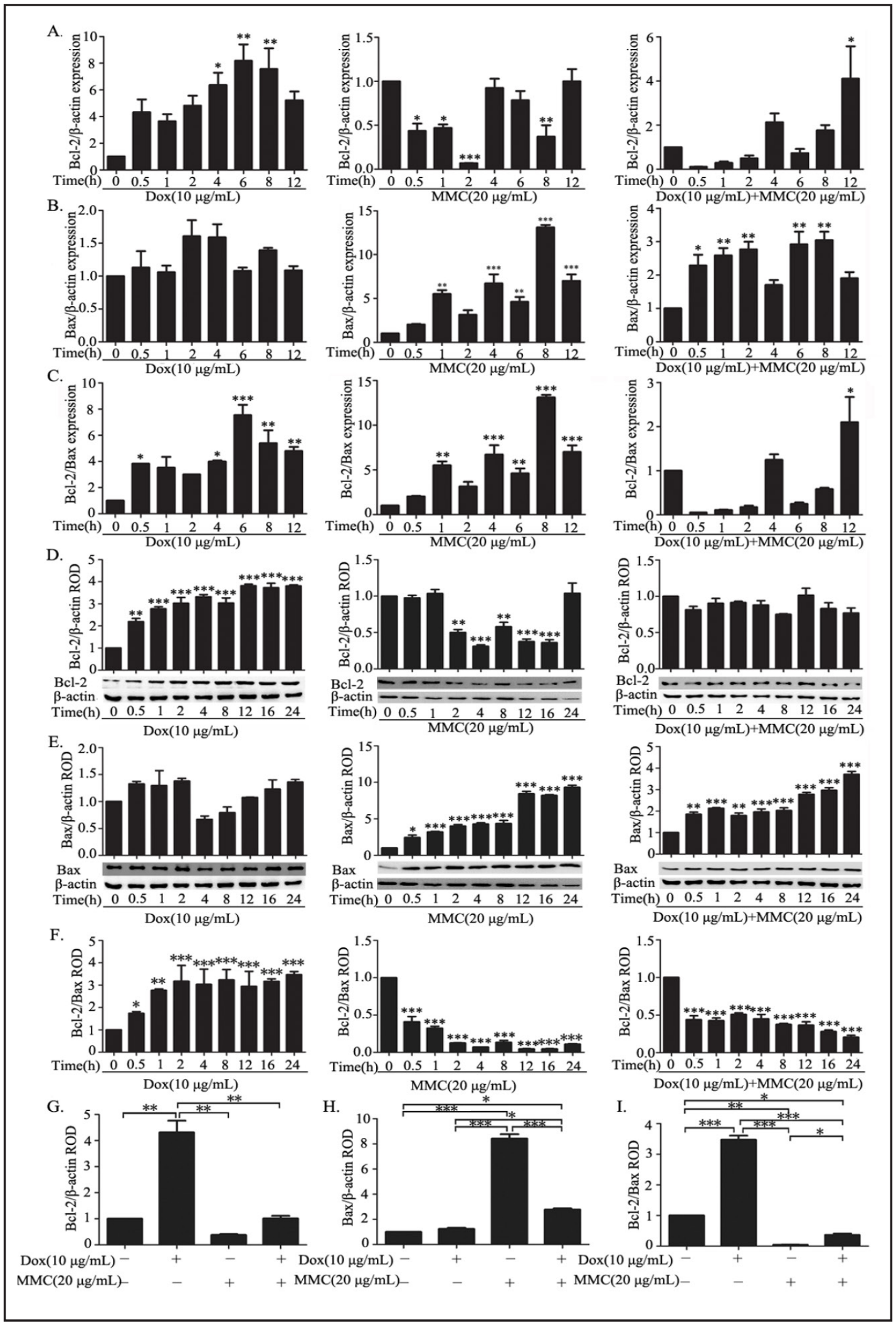

Fig. 5. The effect of Dox on Bcl-2/Bax levels in MTEC1 cells. (A) and (B) Bcl-2 and Bax expression at mRNA level in MTEC1 cells were analyzed by real-time PCR after MTEC1 cells was treated with Dox, MMC and Dox plus MMC for different time. (C) Bcl-2/Bax mRNA expression in MTEC1 cells treated with Dox, MMC and Dox 


\section{Cellular Physiology Cell Physiol Biochem 2016;38:449-460 \\ \begin{tabular}{ll|l} 
DOI: 10.1159/000438642 & O 2016 The Author(s). Published by S. Karger AG, Basel \\
www.karger.com/cpb
\end{tabular} \\ Wang et al.: Dox Protects MTEC1 Cell from Apoptosis}

plus MMC for different time. (D) and (E) Bcl-2 and Bax protein expression in MTEC1 cells were analyzed by western blot after MTEC1 cells was treated with Dox, MMC and Dox plus MMC for different time. (F) The Bcl-2/Bax ROD in MTEC1 cells treated with Dox, MMC and Dox plus MMC for different time. (G), (H) and (I) The Bcl-2/ $\beta$-actin ROD, Bax/ $\beta$-actin ROD and Bcl-2/Bax ROD in MTEC1 cells pretreated with Dox for $12 \mathrm{~h}$ and then treated with MMC for another $12 \mathrm{~h}^{*} p<0.05$, ${ }^{* *} p<0.01,{ }^{* * *} p<0.005$, compared with control "0 h". ROD: relative optical density.

It was demonstrated that Dox could increase the expression level of $\mathrm{Bcl}-2$ and decrease that of Bax (Fig. 5).

\section{Discussion}

The thymus is a primary immune organ in vertebrates. Within the thymus, several cell populations can be found, including thymic stromal cells and developing $\mathrm{T}$ cells of a hematopoietic origin. T cells undergo a process of extensive "education" for export to the periphery culminating in the establishment of a functional and effective adaptive immune system. Stromal cells include epithelial cells of the thymic cortex and medulla, along with dendritic cells allow for the selection of a functional and self-tolerant $\mathrm{T}$ cell repertoire. Therefore, the thymus is essential for maintaining immune homeostasis. More importantly, the thymus is at its largest and most active during the neonatal and pre-adolescent periods. Unfortunately, by early adolescence, the thymus begins to atrophy, shrinks with age, and exhibits changes in its architecture. With aging, stroma is replaced by adipose tissue and a reduced output of naive T cells occurs $[1,5]$. Concurrently with thymic involution, TCR diversity drops. Loss of thymic function and TCR diversity is thought to contribute to weaker immunosurveillance in elderly individuals, including increased occurrence of diseases that include cancers, autoimmunity, and opportunistic infections[5].

Additional, the thymus has been shown to undergo acute thymic atrophy or involution under certain circumstances, such as stress [22], infection [23], pregnancy [24], malnutrition [25], dexamethasone, chemotherapy, ionizing radiation, and hematopoietic stem cell transplantation $[26,27]$. It has been reported that thymic atrophy or involution is plastic, meaning that it can be therapeutically halted or reversed. Keratinocyte growth factor (KGF) [28] and interleukin (IL)-7 [29, 30] are effective cytokines that can reverse atrophy of the thymus. However, KGF can also promote the proliferation of epithelial cancer cells [31, 32], and IL-7 largely contributes to T cell development but does not rescue the senescence of TECs [30].

Cellular apoptosis and abnormal expression of Bcl-2 and Bax have been implicated in the mechanisms underlying thymic involution and/or senescence [33, 34]. Bcl-2 family member proteins play critical roles in cell survival and apoptosis, and they consist of two sub-groups: anti-apoptotic and pro-apoptotic proteins. Bcl-2 is a very important protein that can inhibit cell apoptosis, whereas Bax can promote cell apoptosis $[18,19]$. The ratio of Bcl2-to-Bax determines whether a cell survives or undergoes apoptosis [20].

Dox has been shown to both inhibit proliferation and invasiveness of cancer cells [3537], and also to protect neurocytes from apoptosis by directly inhibiting the enzymatic activity of PARP-1 $[6,38,39]$. However, the details of the mechanism involved remain unclear. In this present study, we have shown that Dox could protect the MTEC1 thymic epithelial cell line from apoptosis induced by MMC. Indeed, the protective role of Dox occurred in the early stage of apoptosis declined from $18.2 \pm 2.1 \%$ to $12.1 \pm 3.3 \%$ at $36 \mathrm{~h}$, while the rate of late stage of apoptosis, treated with or without Dox, is close to $30 \%$ at $36 \mathrm{~h}$, there was relatively large statistic difference in late stage of apoptosis (Fig. 4 and 5). Therefore, we consider the protective effect of Dox is associated with early stage of apoptosis; the potential mechanism needs further study. Bcl-2 and Bax are downstream of NF- $\mathrm{KB}$ [21], so we speculated that Dox might rescue TECs from apoptosis via the NF- $\mathrm{BB}$ signaling pathway and regulate the balance 


\section{Cellular Physiology Cell Physiol Biochem 2016;38:449-460

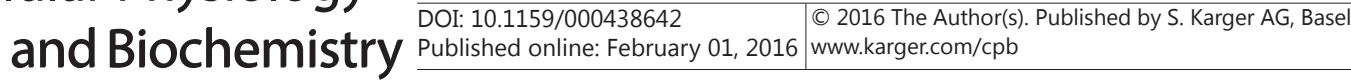 \\ Wang et al.: Dox Protects MTEC1 Cell from Apoptosis}

between Bcl-2 and Bax levels. Our results showed that Dox promoted NF- $\mathrm{B}$ phosphorylation and increased Bcl-2 expression and the Bcl-2-to-Bax ratio. By contrast, MMC inhibited the phosphorylation of NF- $\mathrm{KB}$, reduced $\mathrm{Bcl}-2$ expression and the ratio of $\mathrm{Bcl}-2$-to-Bax, and increased the expression of Bax (Fig. 4 and 5). After pretreatment with Dox and continuous treatment with MMC, the protein expression level of Bcl-2 did not obviously change, but the mRNA level increased, the expression of Bax was somewhat decreased, and the ratio of Bcl2-to-Bax was partly rescued in MTEC1 cells (Fig. 4 and 5).

Previously, Dox has been shown to promote MTEC1 cell proliferation and cytokine synthesis. Using SELDI-TOF MS, we demonstrated that Dox up-regulated the expression of thioredoxin (Trx) [40]. Trx belongs to a class of small redox proteins and has an active conserved site, Cys-Pro-Gly-Cys, that is essential for its function as both an active oxidoreductase and an electron donor of some peroxiredoxins, which are important molecules for the reduction of peroxides. Trx is an important regulator of the redox balance within a cell and has been implicated as an anti-apoptosis and cell survival factor in many contexts, including cancer and neurodegenerative diseases [41]. Trx has two major isoforms, Trx1 and Trx2. Trx1 has been reported to be a cytoplasmic protein, whereas Trx2 shows a mitochondrial localization. In Dox-treated MTEC1 cells, we found that the Trx 2 was markedly up-regulated. However, Trx2 was down-regulated by MMC in MTEC1 cells and showed no long-lasting change in MTEC1 cells that were treated with MMC plus Dox. It has been shown that Trx2 can inhibit cell apoptosis via inhibition of the ASK1/JNK signaling pathway [42]. In conclusion, Dox protects TECs from apoptosis via the NF- $\mathrm{KB}-\mathrm{Bcl}-2 / \mathrm{Bax}$ and Trx2-ASK1/JNK signaling pathways and may serve as a novel reagent for the treatment of thymic atrophy. Of course, understanding the detailed anti-apoptotic mechanisms triggered by Dox in TECs will require further study.

\section{Abbreviations}

Dox (Doxycycline); MMC (Mitomycin C); MTEC1 (Mouse thymic medullar-type epithelial cell line 1); FCM (Flow Cytometry); Trx2 (Thioredoxin2); NF- $\mathrm{B}$ (Nuclear factor kappa B).

\section{Acknowledgements}

The authors would like to thank Professor K. Piper for histopathological diagnosis of clinical specimens. This work was supported by the following grants: The National Natural Science Foundation of China (Grant numbers: 30671984, 81273202, 31200676, 31400773, and 81172834), Clinical Medicine Science \& Technology Project of Jiangsu province of China (Grant number: BL2013024), the Natural Science Foundation of the Jiangsu Higher Education Institutions of China (Grant number: 14KJB320001), Senior Talents Scientific Research Foundation of Jiangsu University (Grant number: 14JDG042), Jiangsu Province Postdoctoral Research Foundation, China(Grant number: 1402170C), Program of Innovative Research Team of Jiangsu Province China, Project Funded by the Priority Academic Program Development of Jiangsu Higher Education Institutions and Project Funded by the Key Academic Program Development of Jiangsu University (Grant number: 1291270019). The Postgraduate Students' Innovation Program of General Higher Education of Jiangsu province of China (Grant numbers: CX10B_283Z, CXZZ11_0591, CXLX12_0675).

\section{Disclosure Statement}

The authors have no conflicts of interest to declare. 


\section{Cellular Physiology Cell Physiol Biochem 2016;38:449-460

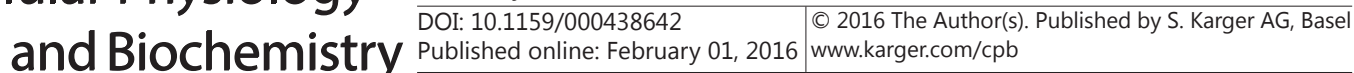 \\ Wang et al.: Dox Protects MTEC1 Cell from Apoptosis}

\section{References}

1 Shanley DP, Aw D, Manley NR, Palmer DB: An evolutionary perspective on the mechanisms of immunosenescence. Trends Immunol 2009;30:374-381.

2 Bar-Dayan Y, Afek A, Goldberg I, Kopolovic J: Proliferation, apoptosis and thymic involution. Tissue Cell 1999;31:391-396.

3 Kelly RM, Goren EM, Taylor PA, Mueller SN, Stefanski HE, Osborn MJ, Scott HS, Komarova EA, Gudkov AV, Hollander GA, Blazar BR: Short-term inhibition of p53 combined with keratinocyte growth factor improves thymic epithelial cell recovery and enhances T-cell reconstitution after murine bone marrow transplantation. Blood 2010;115:1088-1097.

4 Mackall CL, Punt JA, Morgan P, Farr AG, Gress RE: Thymic function in young/old chimeras: substantial thymic $\mathrm{T}$ cell regenerative capacity despite irreversible age-associated thymic involution. Eur J Immunol 1998;28:1886-1893.

5 Lynch HE, Goldberg GL, Chidgey A, Van den Brink MR, Boyd R, Sempowski GD: Thymic involution and immune reconstitution. Trends Immunol 2009;30:366-373.

6 Anlar B, Senbil N, Guven A: Doxycycline in autoimmune central nervous system disorders in children: an in vitro study. Turk J Pediatr 2007;49:274-277.

7 Wu W, Yu LH, Ma B, Xu MJ: The inhibitory effect of doxycycline on cisplatin-sensitive and -resistant epithelial ovarian cancer. Plos One 2014;9:e89841.

8 Woo PC, Tsoi HW, Wong LP, Leung HC, Yuen KY: Antibiotics modulate vaccine-induced humoral immune response. Clin Diagn Lab Immunol 1999;6:832-837.

9 Pomorska-Mol M, Kwit K, Markowska-Daniel I, Pejsak Z: The effect of doxycycline treatment on the postvaccinal immune response in pigs. Toxicol Appl Pharmacol 2014;278:31-38.

10 D'Agostino P, Ferlazzo V, Milano S, La Rosa M, Di Bella G, Caruso R, Barbera C, Grimaudo S, Tolomeo M, Feo S, Cillari E: Anti-inflammatory effects of chemically modified tetracyclines by the inhibition of nitric oxide and interleukin-12 synthesis in J774 cell line. Int Immunopharmacol 2001;1:1765-1776.

11 Chen X, Xia S, Li R, Liu H, Huang Y, Qian X, Xiao X, Xu X, Lin X, Tian Y, Zong Y, He D, Chen W, Zhang Y, Shao Q: Doxycycline enhances the Ras-MAPK signaling and proliferation of mouse thymic epithelial cells. J Cell Biochem 2009;107:494-503.

12 Huang Y, Li R, Chen X, Zhuo Y, Jin R, Qian XP, Jiang YQ, Zeng ZH, Zhang Y, Shao QX: Doxycycline up-regulates the expression of IL-6 and GM-CSF via MAPK/ERK and NF-kappaB pathways in mouse thymic epithelial cells. Int Immunopharmacol 2011;11:1143-1149.

13 Liu ZG, Haelens A, Wuyts A, Struyf S, Pang XW, Proost P, Chen WF, van Damme J: Isolation of a lymphocyte chemotactic factor produced by the murine thymic epithelial cell line MTEC1: identification as a $30 \mathrm{kDa}$ glycosylated form of MCP-1. Eur Cytokine Netw 1996;7:381-388.

14 Ge Q, Chen WF: Effect of murine thymic epithelial cell line (MTEC1) on the functional expression of CD4(+) CD8(-) thymocyte subgroups. Int Immunol 2000;12:1127-1133.

15 Liu X, Xu X, Lin X, Tian Y, Ji B, Xia S, Xu S, Yin Q, Zhang M, Jiao Z, Wang S, Xu H, Shao Q: PTD-hFOXP3 protein acts as an immune regulator to convert human CD4(+)CD25(-) T cells to regulatory T-like cells. J Cell Biochem 2012;113:3797-3809.

16 Li GY, Fan B, Jiao YY: Rapamycin attenuates visible light-induced injury in retinal photoreceptor cells via inhibiting endoplasmic reticulum stress. Brain Res 2014;1563:1-12.

17 Psarra AM, Hermann S, Panayotou G, Spyrou G: Interaction of mitochondrial thioredoxin with glucocorticoid receptor and NF-kappaB modulates glucocorticoid receptor and NF-kappaB signalling in HEK-293 cells. Biochem J 2009;422:521-531.

18 van Delft MF, Huang DC: How the Bcl-2 family of proteins interact to regulate apoptosis. Cell Res 2006;16:203-213.

19 Eberle J, Hossini AM: Expression and function of bcl-2 proteins in melanoma. Curr Genomics 2008;9:409419.

20 Raisova M, Hossini AM, Eberle J, Riebeling C, Wieder T, Sturm I, Daniel PT, Orfanos CE, Geilen CC: The Bax/ Bcl-2 ratio determines the susceptibility of human melanoma cells to CD95/Fas-mediated apoptosis. J Invest Dermatol 2001;117:333-340.

21 Luna-Lopez A, Gonzalez-Puertos VY, Romero-Ontiveros J, Ventura-Gallegos JL, Zentella A, GomezQuiroz LE, Konigsberg M: A noncanonical NF-kappaB pathway through the p50 subunit regulates Bcl-2 overexpression during an oxidative-conditioning hormesis response. Free Radic Biol Med 2013;63:41-50.

22 Dominguez-Gerpe L, Rey-Mendez M: Evolution of the thymus size in response to physiological and random events throughout life. Microsc Res Tech 2003;62:464-476. 


\section{Cellular Physiology Cell Physiol Biochem 2016;38:449-460 \begin{tabular}{l|l|l|l} 
DOI: 10.1159/000438642 & O 2016 The Author(s). Published by S. Karger AG, Basel \\
anw.karger.com/cpb
\end{tabular} \\ Wang et al.: Dox Protects MTEC1 Cell from Apoptosis}

23 Savino W, Dardenne M, Velloso LA, Dayse Silva-Barbosa S: The thymus is a common target in malnutrition and infection. Br J Nutr 2007;98:S11-16.

24 Kendall MD, Clarke AG: The thymus in the mouse changes its activity during pregnancy: a study of the microenvironment. J Anat 2000;197:393-411.

25 Howard JK, Lord GM, Matarese G, Vendetti S, Ghatei MA, Ritter MA, Lechler RI, Bloom SR: Leptin protects mice from starvation-induced lymphoid atrophy and increases thymic cellularity in ob/ob mice. J Clin Invest 1999;104:1051-1059.

26 van den Brule S, Huaux F, Uwambayinema F, Ibouraadaten S, Yakoub Y, Palmai-Pallag M, Trottein F, Renauld JC, Lison D: Lung inflammation and thymic atrophy after bleomycin are controlled by the prostaglandin D2 receptor DP1. Am J Respir Cell Mol Biol 2014;50:212-222.

27 Mackall CL, Fleisher TA, Brown MR, Andrich MP, Chen CC, Feuerstein IM, Horowitz ME, Magrath IT, Shad AT, Steinberg SM, et al.: Age, thymopoiesis, and CD4+ T-lymphocyte regeneration after intensive chemotherapy. N Engl J Med 1995;332:143-149.

28 Alpdogan O, Hubbard VM, Smith OM, Patel N, Lu S, Goldberg GL, Gray DH, Feinman J, Kochman AA, Eng JM, Suh D, Muriglan SJ, Boyd RL, van den Brink MR: Keratinocyte growth factor (KGF) is required for postnatal thymic regeneration. Blood 2006;107:2453-2460.

29 Peschon JJ, Morrissey PJ, Grabstein KH, Ramsdell FJ, Maraskovsky E, Gliniak BC, Park LS, Ziegler SF, Williams DE, Ware CB, Meyer JD, Davison BL: Early lymphocyte expansion is severely impaired in interleukin 7 receptor-deficient mice. J Exp Med 1994;180:1955-1960.

30 Liang CC, You LR, Yen JJ, Liao NS, Yang-Yen HF, Chen CM: Thymic epithelial beta-catenin is required for adult thymic homeostasis and function. Immunol Cell Biol 2013;91:511-523.

31 Kesinger JW, Mehta M, Lerner MR, Brackett DJ, Brueggemeier RW, Li PK, Pento JT: Oncolytic potential of a novel KGFR tyrosine kinase inhibitor using a KGFR-selective breast cancer xenograft model. Anticancer Res 2015;35:47-52.

32 Finch PW, Rubin JS: Keratinocyte growth factor expression and activity in cancer: implications for use in patients with solid tumors. J Natl Cancer Inst 2006;98:812-824.

33 Talaber G, Kvell K, Varecza Z, Boldizsar F, Parnell SM, Jenkinson EJ, Anderson G, Berki T, Pongracz JE: Wnt-4 protects thymic epithelial cells against dexamethasone-induced senescence. Rejuvenation Res 2011;14:241-248.

34 Kanavaros P, Stefanaki K, Rontogianni D, Papalazarou D, Sgantzos M, Arvanitis D, Vamvouka C, Gorgoulis V, Siatitsas I, Agnantis NJ, Bai M: Immunohistochemical expression of p53, p21/waf1, rb, p16, cyclin D1, p27, Ki67, cyclin A, cyclin B1, bcl2, bax and bak proteins and apoptotic index in normal thymus. Histol Histopathol 2001;16:1005-1012.

35 Song H, Fares M, Maguire KR, Siden A, Potacova Z: Cytotoxic Effects of Tetracycline Analogues (Doxycycline, Minocycline and COL-3) in Acute Myeloid Leukemia HL-60 Cells. PLoS One 2014;9:e114457.

36 Lamb R, Ozsvari B, Lisanti CL, Tanowitz HB, Howell A, Martinez-Outschoorn UE, Sotgia F, Lisanti MP: Antibiotics that target mitochondria effectively eradicate cancer stem cells, across multiple tumor types: Treating cancer like an infectious disease. Oncotarget 2015;6:4569-4584.

37 Griffin MO, Fricovsky E, Ceballos G, Villarreal F: Tetracyclines: a pleitropic family of compounds with promising therapeutic properties. Review of the literature. Am J Physiol Cell Physiol 2010;299:C539-548.

38 Alano CC, Kauppinen TM, Valls AV, Swanson RA: Minocycline inhibits poly(ADP-ribose) polymerase-1 at nanomolar concentrations. Proc Natl Acad Sci USA 2006;103:9685-9690.

39 Tikka T, Usenius T, Tenhunen M, Keinanen R, Koistinaho J: Tetracycline derivatives and ceftriaxone, a cephalosporin antibiotic, protect neurons against apoptosis induced by ionizing radiation. J Neurochem 2001;78:1409-1414.

40 Zhuo Y LH, Jiang YQ, He DC, Chen WF, Shao QX: Analysis of the protein expression profile of thymic epithelial cells treated with or without doxycycline action. Journal of Jiangsu University (Medicine Edition) 2011;21:298-302.

41 Silva-Adaya D, Gonsebatt ME, Guevara J: Thioredoxin system regulation in the central nervous system: experimental models and clinical evidence. Oxid Med Cell Longev 2014;2014:590808.

42 Dunn LL, Buckle AM, Cooke JP, Ng MK: The emerging role of the thioredoxin system in angiogenesis. Arterioscler Thromb Vasc Biol 2010;30:2089-2098. 